\title{
Social support as the role of social worker in work with dialysed clients
}

\author{
N. Kovalcikova and J. Zakova \\ Trnava University in Trnava, Trnava, Slovakia
}

\begin{abstract}
The quality of life of individuals with chronic illness is strongly influenced by anticipated social support. In this regard we wanted to know how social support is reflected (perceived) in dialysis patients. The aim of the study was to measure the level of perceived social support in patients undergoing dialysis treatment. We utilized a quantitative research strategy using a standardized social support questionnaire - MOS. The respondents of the survey were clients of dialysis centres in Slovakia undergoing dialysis or peritoneal dialysis and willing to participate in our research. The results showed statistically significant difference in the perception of social support depending on the status of cohabitation. We did not find any significant difference relating to the type of dialysis treatment, its duration, age of respondents, involvement in self-help groups and the use of social services and compensations. The results show that the family acts as the key factor of providing social support and that family support is of the utmost importance for clients who undergo dialysis treatment. The study also contains recommendations for social work.
\end{abstract}

\section{Introduction}

Chronic kidney diseases are now a global problem that has an increasing tendency in developed countries. It is estimated that one of ten people in our population suffers from a type of kidney disease. Kidney diseases are becoming not only medical, but also socioeconomic problem [1]. When kidneys fail to function properly, a complex nephrology treatment must start, in cases of more serious malfunction dialysis is prescribed and the patient undergoes dialysis treatment. Dialysis is a method of purifying blood by removing waist products of nitrogen metabolism, especially urea and creatinine. Kidney dysfunction is treated by dialysis - either haemodialysis or peritoneal dialysis [2].

Along with dialysis, patients must also follow a strict regime and diet as this greatly influences quality of life for both patients and their families. Šafránková and Nejedlá [2] indicate that dialysis also correlates with somatic symptoms in patients - cardiovascular complications, blood-related conditions, digestive disorders and pain. This treatment is accompanied by complications and patients also deal with associated diseases. There are also certain psychiatric issues such as fear, stress, feeling of being dependent on a machine, prospect. Economy-related issues relate to leaving the labour market and receiving disability pension and of course, higher treatment cost. Regarding social aspects, along with this treatment come changes in the life style, hobbies, often with a negative impact on family relations and similar. Znojová and Sulková [3] state that among the greatest stress 
factors in these patients, occur such factors as reduction of physical activities, restricted ability, impairment of body functions, fatigue and fluid restrictions. The total stress score did not significantly vary in sexes and was statistically greater in older dialysis patients (over 50 years old). Kidney malfunction is therefore a burden for people, it can change how people feel, behave and think. Psychosocial influence can have an impact on comfort in the patients and the disease course. One of the possible approaches in dealing with the burden brought by the serious disease is the strategy to gain social support. A sick person seeks for somebody to share his problems with, somebody who could understand. When this social support has been gained, the person usually feels better [4, 5]. Mares [6] defines social support as well-doing that is offered to someone who is close and this activity has either an immediate or later coming positive effect. It can also be defined as help that is offered to people who find themselves in a difficult situation. Social help is important especially when a person falls sick or is affected by an injury, when he or she find themselves in a crisis and has to make a serious decision [7]. Znojová's [8] study of people with serious diagnosis showed that those patients who are given reasonable social support from their family and close people and friends achieve better treatment, cooperate better with healthcare professionals, live longer despite the disease and also the overall quality of their life is higher. Andrášiová [9] also emphasizes that social support is an important protective factor when coping with stress brought by the disease and treatment, especially during the period when the patient is not surrounded by a vast spectrum of personal protective factors. Dobríková [10] adds that lonely people, who only enjoy low social supports in comparison to the control sample, showed a weakening of the immune system.

Social support can be achieved from various sources. We can turn to non-professionals, such as family, friends, colleagues or we can seek help among professionals, this can then be given either individually or in a form of group sessions [11]. Sources of social support are $[12,13]$ either natural, usually represented by close relatives, such as parents, husband, wife, brothers or sisters, friends, etc., or institutions, e.g., non-government organisations, state organisations, support groups that are organised by specialists, self-help groups, religious organisations and helping professions, among which is also social work.

\section{Participants and methodology}

The main goal of the study was to find the degree of anticipated social support in clients undergoing a dialysis treatment. Krpoun [14] points out that anticipated social support can be understood as a feeling of being accepted and belief that there is somebody you can turn to, when it is needed. On the other hand, there is also acquired social support that reflects a specific pattern in interaction between two and more people in a specific situation. As for partial goals, we wanted to determine degree of social support in relation to the type and duration of dialysis treatment, age, cohabitation status, meeting in self-help groups, and receiving disadvantage compensation and social services.

The objects of our study were dialysis clients. Only clients whose health condition was stabilised, who agreed to participate and who were in the process of active dialysis treatment - either haemodialysis or peritoneal - were accepted in the study. The sample group consisted of 182 respondents, with $55 \%$ men and $45 \%$ women. The average age of the study respondents was 64.27 . The respondents were not younger than 15 or older than 90. Of them, $51 \%$ were married, $26 \%$ - over a quarter of the group - were widows or widowers and $17.05 \%$ of the respondents were single. $4 \%$ were unmarried partners and $1 \%$ was divorced. $12 \%$ of the respondents lived on their own, with majority of them being older age and having lost their husband or wife. $37 \%$ of the respondents lived with their husband/wife or partner. $47.73 \%$ of the respondents lived with their family members and 
stated that they lived with their children, son in law or daughter in law. One respondent was a resident of a nursing home. In our sample haemodialysis prevailed, with $86 \%$ of the respondents receiving this type of treatment, $14 \%$ of the respondents received peritoneal dialysis treatment. Most of the respondents, $47 \%$, received dialysis treatment for $1-4$ years, shorter than 1 year $-13 \%$ of the respondents, $5-9$ years $-25 \%$ and more than 10 years $13 \%$ of the respondents. $86 \%$ of the respondents did not attend meetings of self-help groups, while $13 \%$ of the respondents were active in self-help groups.

We used a questionnaire to collect the data. This questionnaire consisted of two parts; the first part dealt with basic questions, demographic information and specification of the dialysis treatment. The second part of the questionnaire consisted of standardised questions for social support MOS. The method Social Support Survey - MOS, used in this study, was developed by Rand and Medical Outcomes Study. This method, designed to be used in general population, measures degree of anticipated social support, reflects subjective interpretation of the individual's social inclusion. The original 50-item group of questions was reduced to 19 questions that covered five dimensions of social support, namely emotional, information, material assistance, social interactions and affective dimension of social support [15]. To have a Slovak version of the questionnaire, we edited a Czech version of the questionnaire that uses three dimensions: Practical Intervention and Emotional Intimacy are equivalents of Tangible Support and Affectionate Support in the American version, items Positive Social Interaction and Emotional/Informational Support are represented in the Czech version as Supportive authority - see the questionnaire for social support - MOS: Vnitřní struktura nástroje [15].

\section{Results and discussion}

Dialysis treatment is necessary when kidneys fail to function. It is a life-saving therapy that allows patients to keep on living, but also brings many restrictions and changes in life. Patients who receive dialysis treatment live in stress, this is brought by both progress of the illness and also the dialysis treatment itself. Unless transplantation is performed, patients with malfunctioning kidneys are dependent on the dialysis treatment for the rest of their lives. Regarding quality of their life and overall satisfaction with life it is important that clients and their families continue as normal life as possible so that they are not completely paralysed by thinking about the illness and treatment procedures. It is social support that can help here; we take it as an important component that helps patients overcome problems and burden that come with their disease and its treatment. By general influence of social support we understand the positive effects that good interpersonal relationship brings in the social network of the person, in everyday life, these can positively influence mental and physical health. Specific influence relates to concrete life situations (stress, distress) [16]. We specifically aimed our research at finding out the level of social support in people receiving treatment in form of haemodialysis or peritoneal dialysis. We used 19 questions in a standardised questionnaire. The patients' answers reflected high rankings in all of the questions, the lowest average rank was 4.27 and highest average rank was 4.69. The most frequently used ranking was 5 . Question number 13, "How often is somebody, who can help you distract from worries, available?" got the lowest average ranking (4.27). This question reflects the supportive authority dimension. For a dialysis patient it is somebody who can help distract his or her worries and is available most of the time. Question number 19 deals with emotional closeness, i.e. how often the person who you like and who needs you is available for you. The top average rating for this question was 4.69. We can say that the person a dialysis patient likes and who needs him/her is always available. The questions dealing with practical intervention dimension got ranking between 4.63 and 4.67 . The 
answers testify that somebody who takes the dialysis patients to the doctor's, who can cook for them when they are not able to do it and who helps them with house chores is commonly available. The questions dealing with emotional closeness also got very high ranking (4.35-4.49). Somebody who can hug the dialysis patient when he or she needs it is available most of the time. There is always somebody who shows affection, compassion and makes them feel well, somebody who cares about them and who needs them. Dimension supportive authority, studied through 11 questions, got just a little lower ranking when compared to the previous two dimensions (4.33-4.49). For dialysis patients, there is usually somebody available, somebody who listens to them, understands their problems, helps them in critical situations, distracts negative thoughts and shares their fears and worries, offers information that is necessary to understand certain situation, somebody they can confess their worries and problems to and who helps them relax, do something that pleases them, somebody whose advice they need and who is ready to help them with personal problems.

In the study, we were strongly interested whether there was a connection between the level of perceived social support and type of dialysis treatment. We started with the assumption that peritoneal dialysis allows more freedom in personal life, but also requires certain social background and often also other people's cooperation during dialysis treatment or care and maintenance of the dialysis catheter. We expected that the level of social support would be appraised considerably higher in the clients undergoing a peritoneal treatment and that the average rankings in the assessment of social support would be higher. We acquired results using the Mann-Whitney $U$ test for two independent variables. This test did not testify a significant difference based on the type of dialysis treatment $(Z=-621, p=0.535)$. Basing on the test results, we can say there was not any statistically important difference in degree of social support based on type of dialysis.

Duration of a dialysis programme has a great influence on patient's mental health. Mortality rate during dialysis treatment is still high despite improvement in care of such patients. $80 \%$ of patients survive in the first year of treatment, but only half of the patients live longer than 5 years. Apart from kidney disease, patients also suffer from co-morbidities (subsidiary illness, especially diabetes mellitus and arterial hypertension). Unfortunately, a large group of ill people do not know about their disease, have never been checked up and suddenly have to start a dialysis treatment $[1,17]$. It is also a sort of intermediate station, where patients who are given dialysis treatment wait for kidney transplantation that greatly improves quality of their life. The length of the waiting time is individual and the success or failure of transplantation is determined by various factors that the patient cannot influence. During this time patients experience states of ambivalence that are brought not only by dialysis itself, but also by feeling hope/despair when they wait for the transplantation. Basing on these arguments, we assumed that there would be statistically significant difference in assessing degree of social support that relate to the duration of dialysis treatment $(H(3)=5.680, p=0.128)$. The lowest ranking of social support was found in patients who had received dialysis treatment for between 1-4 years (83.40) and the highest ranking was in patients that had been in dialysis programme for 5-9 years.

Basing on Šolcová and Kebza's [18] findings, age was taken as one of the predictors for social support. Therefore we wanted to see in our study whether there were any age-related differences in anticipated social support ranking. However, the Kruskal Wallis test did not testify this $(H(4)=2.704, p=0.608)$. In practical intervention, the lowest value of 17.83 was found in dialysis patients between 30 and 44 years old and highest values of 20.00 were seen in 60-74 years old patients. In the dimension of emotional closeness, the lowest value of 17.86 was seen in 45-59 years old patients and the highest value of 18.75 was in 60-74 years old patients. The lowest result of 47.91 in the dimension of supportive authority was in the 75-89 age group and the highest, 50.50, in the 15-29 age group. This 
was probably related to the fact that the youngest respondents did not live on their own, and in contrast, in older age social interactions are somewhat limited, as Špatenková [19] and Stuart-Hamilton [20] claim.

We agree with Vágnerová [5] that a serious disease does not affect only the sick person, but brings its consequences also to the whole family. For a sick person, it is the family that is his or her social group, the social group that helps with social integration and thus makes it accessible and approachable, the social group that also offers emotional safety and support. Kebza [21] sees family and family relations as a crucial factor here; family is often used as index of social support. Ondrušová et al. [12] understands family as the most important tool of social help. We understand the fact that this was proven to be the most important outcome. Basing on the claims mentioned above, we wanted to find out whether there was a significant difference in the scope of declared social support in relation to the different status of mutual cohabitation. It was confirmed that there were differences in perceiving the scope of social support in dialysis patients with different form of cohabitation $(H(3)=10.725, p=0.013)$. There was a difference between respondents that lived alone and respondents that lived with their wife/husband, partner or with their family. Those dialysed patients who lived alone appraised the overall social support almost $50 \%$ lower than clients who lived with their spouse or partner. The acquired results showed that social connection with partners, families or relatives positively influences the social support appraisal. In connection to this, Andrášiová [9] points out that sick people who enjoy support from their family are commonly more active and better motivated to fight the disease. The Mann-Whitney $U$ test testified that there are differences in social support appraisal between those who live alone and those who live with their family. The significance value in overall social support $p=0.003$, practical intervention $p=0.007$, emotional closeness $p=0.002$ and the dimension of supportive authority $p=0.009$. Research study performed by Dobríková [10], which can be implemented and used also for work with dialysis patients and their relatives, revealed that people with tumours need their relatives to use natural approach in communication, body language that agrees with words they say, support and adequate help, encouragement, respect and tolerance. The need of physical touch is individual, some patients do not like more frequent physical touches, they need understanding especially in the period when they are temporarily emotionally unstable, they appreciate positive news about their surrounding and need others to respect a new daily regime and another changes that are triggered by the illness. However, Mátel and Hardy [22] argue that families differ in their ability to function properly even under pressure. Some families can cope with problems and need support during only a more stressful period; other families need permanent help from organisations and authorities.

For another assumption, we started with arguments presented by Schavel et al. [23] who, basing on research conducted abroad, points out that members of self-help groups are more independent, have greater possibilities for social contact than other people in similar situation and are also less prone to depressions. In self-help groups that consist of parents with chronically ill children, where the parents help each other, was found a very positive influence brought by social support provided by the self-help group [4]. We therefore wanted to know whether there was a relation between degree of anticipated social support and meeting in self-help groups. Surprisingly, the result value determined by the MannWhitney $U$ test showed there was no difference in degree of declared social support among dialysed patients who met in self-help groups and those who did not $(Z=412.500, p=$ $0.593)$. Similarly, there were no statistically significant differences testified in individual dimensions of social support, practical intervention $p=0.968$, emotional closeness $p=$ 0.734 , supportive authority $p=0.538$. We believe that this result could have been influenced by the small number of participants in our sample group of people who met in self-help groups. Yet, Krrivohlavý [4] notices that meeting in self-help groups is an 
increasing practice. An individual person looks for somebody who could help. Self-help groups are thus becoming an important addition to the system of health care. The majority of respondents who meet in self-help groups were at least 45 years old. We had expected that younger respondents meet in self-help groups in a larger number. It may have been influenced also by the fact that there were fewer respondents of this age group (44 years old and younger) in our sample group, but also because the average age of dialysed clients in our sample group was 64 .

We would like to speak about a broader character of social support regarding its levels (macro-level, mezzo-level, micro-level) that generally distinguish those who provide social support in regard to their distance from receivers of social support. Krrivohlavý [16], Šolcová and Kebza [24] speak about macro-level, which means help form the state and which is also recognised in legislative. As an example, we can take the instrumental assistance (practical assistance or material assistance) and information assistance (providing guidance or advice) that is offered by social workers. We were therefore interested in the extent people used social assistance, social services, disability benefits for seriously disabled people receiving dialysis treatment. Regarding Slovak legislation provisions that are applied in social services, benefits to the seriously disabled, health care (Act No. $447 / 2008$ regarding disability benefits, amendments and modifications to certain laws, Act No. 448/2008 regarding social services, as amended, Act No. 577/2004 on the scope of health care, as amended), we asked in question 13 whether dialysed patients used social services or benefits to compensate the impact of the serious health condition. $21 \%$ of the respondents stated that they used social services and 79\% answered "no". Question 14 "Do you receive financial compensation?" was answered "yes" by $70 \%$ of the respondents, while $30 \%$ of the respondents answered "no". The answers indicate that chronic kidney disease and dialysis treatment influence negatively the economical perspective of life in dialysis patients and compensations can be understood as an effort for a micro-level social support that can be given by the state. We tested statistically also whether there was a corelation between the scope of social support and extent to which people apply for social services or compensation benefits for their serious health condition. Our assumption was not confirmed here.

Chronic renal insufficiency and following dialysis treatment are health conditions that mean long-time burden for the sick people and their close but also wider social surrounding. Social assistance in the form of emotional, instrumental and material support is a significant factor for coping chronic stress. The results of our study show that family is the primary source of social support in people who undergo a dialysis treatment. In our sample group, the extent of social support was dependent neither on age of the patients, type and duration of a dialysis treatment, nor on macro-level help - using social assistance and receiving benefits to compensate a serious health condition.

This paper was prepared as a part of the project The Identity of Social Work in the Context of Slovakia [APVV-0524-12] funded by the Slovak Research and Development Agency.

\section{References}

1. R. Ryšavá. Chronické onemocnění ledvin- role nefrologa a praktického lékarě. Via Practica. ISSN 1336-4790, 2015 , issue 2, 12, p. 87-89. (2015)

2. A. Šafránková, M. Nejedlá. Interní ošetrovatelství II. 212 p. ISBN 80-247-1777-8. (Praha: Grada Publishing, a. s.2006)

3. M. Znojová, S. Sulková. Hodnocení stresu u dialyzovaných pacientú. Časopis lékařu českých [online]. 2001, issue 4, p. 108-111. Available on the Internet at 
http://www.prolekare.cz/casopis-lekaru-ceskych-clanek/ hodnoceni-stresu-u-dialyzovanych-pacientu-25786. (2001)

4. J. Křivohlavý. Psychologie nemoci., 200 p. ISBN 80-247-0179-0. (Praha: Grada Publishing, 2002)

5. M. Vágnerová. Současná psychopatologie pro pomáhajíci profese. 816 p. ISBN 97880-262-0696-5. (Praha: Portál, s. r. o, 2014)

6. J. Mares. Nevyužívání či odmítaní sociální opory. Psychológia a patopsychológia diet'at'a. ISSN: 055-5574, 2001, 36, 3, p.214-224. (2001)

7. J. Křivohlavý. Psychologie zdraví. 280 p. ISBN 80-7178-551-2. (Praha: Portál, 2001)

8. M. Znojová. Kvalita života peritoneálne dialyzovaných pacientu. Stežeň [online]. 2005. 16, 2. Available on the Internet at http://stezen.xf.cz/html/ stezen/2005/0502.html

9. M. Andrášiová. Psychologické minimum o psychickom prežívaní onkologického pacienta. Via practica. Solen. [online]. 2007, 4, p. 42-46 Available on the Internet at http: / / www.solen.sk/pdf/7f83efdd5580e66f37f104ac3c86bf9a. pdf

10. P. Dobríková. Zvládanie zát’ažových situácií. Ako si zachovat' duševné zdravie. 126 p. ISBN 978-80-89271-20-7 (Bratislava: SAP - Slovak Academic Press, 2007)

11. V. Hanzalíková, K. Levická. Sociálna opora v procese smútenia. Solen [online]. 2012, 5, issue 2, p. 43-45 Available on the Internet at http: / /www. solen.sk/ pdf / b905064bdede79a4a2e8ea896e4aeb7a.pdf (2012)

12. Z. Ondrušová. Základy sociálnej práce. 144 p. ISBN 978-807392-109-5. (MSD Brno, 2009)

13. J. Levická. Sociálna práca I., 168 p. ISBN 978-80-969454-2-9. (Trnava: OLIVA, 2007)

14. Z. Krpoun. Sociální opora: Shrnutí výzkumné činnosti v české a slovenské oblasti a inspirace do budoucnosti- nadané děti. E-Psychologie, Elektronický časopis ČMPS [online], 2012, year 6, issue 1, p. 42-50. Available on the Internet at: http://epsycholog.eu/pdf/krpoun.pdf

15. J. Kožený, L. Tišanská. Dotazník sociální opory - MOS: Vnitřní struktura nástroje. Československá psychologie. ISSN 0009-062X, 2003, 47, 2, p. 135-143. (2003)

16. J. Křivohlavý. Psychologie zdraví. 280 p. ISBN 978-80-7367-568-4. 78 (Praha: Portál,s.r.o., 2009)

17. A. OKŠA. Diabetická nefropatia- diagnostika, prevencia a liečba: Odporúčané postupy Slovenskej nefrologickej spoločnosti a Slovenskej diabetologickej spoločnosti. Forum diabetologicum. ISSN 1805-3807, 2013, 2, 2, p. 51-56. (2013)

18. I. Šolcová, V. Kebza. Prediktory sociální opory u české populace. Československá psychologie. ISSN 0009-062X, XLVII, 3, p. 220-226. (2003)

19. N. Špatenková. Krize. Psychologický a sociologický fenomén. 129 p. ISBN 80-2470888-4 (Praha: Grada, 2004)

20. I. Stuart Hamilton. Psychologie stárnutí. 319 p. ISBN 80-7178-274-2 (Praha: Portál, 1999)

21. V. Kebza, Psychosociální determinanty zdraví. p. 296. ISBN 80-200-1307-5 (Praha: Academia, 2005)

22. A. Mátel, M. Hardy. Vybrané kapitoly z metód sociálnej práce II. 507 p. ISBN 978808131-074-3. (Bratislava: Vysoká škola zdravotníctva a sociálnej práce sv. Alžbety, 2013) 
23. M. Schavel. Sociálna prevencia. 267 p. ISBN: 978-80-89271-22-1. 80 (Bratislava: Vysoká škola zdravotníctva a sociálnej práce sv. Alžbety, 2010)

24. I. Šolcová, V. Kebza. Sociální opora jako významný protektivní faktor. Československá psychologie. ISSN 0009-062X, 1999, 43, 1, p. 19-38. (1999) 